Research Article

Maciej Gis, Jacek Pielecha*, and Wojciech Gis

\title{
Exhaust emissions of buses LNG and Diesel in RDE tests
}

https://doi.org/10.1515/eng-2021-0038

Received Sep 13, 2020; accepted Jan 03, 2021

Abstract: The article compares the exhaust emissions in road conditions of city buses: LNG and Diesel. Both buses met the Euro VI exhaust emission norm. The current strong drive to diversify fuels in Poland and the creation of a large gas port in Świnoujście for LNG imports creates an excellent opportunity to use this fuel, also in road transport. Therefore, the attempt to identify the emission in operation, in first place possible applications, i.e. an LNG bus, comparatively with the emission of a Diesel bus. The operational research carried out concerned such a bus and has not yet been carried out in the country, hence their innovation, also methodological. The conducted research, in particular, was aimed at verifying differences in exhaust emissions of carbon dioxide and nitrogen oxides. The study was carried out on one urban bus route performing trips on consecutive days in similar environmental conditions. The performed tests were not strictly type approval tests but only used for comparative purposes. Hence, it was necessary to determine the compliance factor for the relevant exhaust gas substances, with the use of an evaluation algorithm based on measurement windows. Based on these results, the assumption regarding compliance with the emission requirements for the tested buses was verified in real traffic conditions. The exhaust emission values (emission indicators) determined in this way did not exceed the permissible emission limit values for carbon monoxide, while for nitrogen oxides and non-methane hydrocarbons certain exceedances were found.

Keywords: exhaust emissions; city buses; alternative fuels; real driving emissions

${ }^{\star}$ Corresponding Author: Jacek Pielecha: Poznan University of Technology, Faculty of Civil and Transport Engineering, Piotrowo Street 3, 60-965 Poznan, Poland; Email: jacek.pielecha@put.poznan.pl Maciej Gis, Wojciech Gis: Motor Transport Institute, Jagiellonska Street 81, 03-301 Warsaw, Poland

əopen Access. (c) 2021 M. Gis et al., published by De Gruyter. (Cc) BY License

\section{List of symbols and abbreviations}

a

CF

CNG

CO

$\mathrm{CO}_{2}$

e

EC

EEA

EU

FID

GPS

L

LNG

m

NOx

NDIR

NDUV

NMHC

PEMS

pkm

SCR

SI

$\mathbf{t}$

$\mathbf{T}$

THC

W

WHTC

V acceleration, $\mathrm{m} / \mathrm{s}^{2}$

conformity factors

compressed natural gas

carbon monoxide

carbon dioxide

specific exhaust emissions, $\mathrm{mg} / \mathrm{kWh}$

European Commission

European Environment Agency

European Union

flame-ionization

global positioning system

maximum emission limit, $\mathrm{mg} / \mathrm{kWh}$

liquid natural gas

mass, mg

nitrogen oxides

non-dispersive infrared

non-dispersive ultraviolet

non-methane hydrocarbons

portable emission measurement system

passenger kilometre

selective catalytic reduction

spark ignition

time, s

temperature

total hydrocarbons

work, kWh

World Harmonized Transient Cycle

velocity, $\mathrm{km} / \mathrm{h}$

\section{Introduction}

The European Union's climate policy, aimed at limiting climate change, has a significant impact on the transport sector by requiring the reduction of greenhouse gas emissions. According to the estimates of the European Environment Agency, the transport sector was responsible for over $25 \%$ of the greenhouse gas emissions in the European Union in 2015. Of the total carbon dioxide mass emitted from transport about $25 \%$ was generated by urban trans-

This work is licensed under the Creative Commons Attribution 4.0 
port. The provisions of the European Union (including the White Paper on Transport) are aimed at reducing pollution and increasing transport efficiency and promote increasing the importance of public transport as well as reducing the consumption of petroleum-derived fuels in favour of alternative fuels. According to the adopted transport policy, greenhouse gas emissions by 2030 should amount to only $20 \%$ of the emissions of these gases in 2008, while carbon dioxide emissions should amount to $40 \%$ of the values in 1990. In order to meet these requirements, reducing the number of vehicles with diesel engines in urban transport by $50 \%$ by the year 2030 should help, finally leading to their elimination by the end of 2050 . Such a goal should be supported by the implementation of solutions provided for in the European Parliament Directives on environmentally friendly energy-saving road transport vehicles.

The required reduction of exhaust emissions can be achieved thanks to technical changes made to vehicles mainly by changing the propulsion type and fuels, reduction of energy consumption and correct transport management. Currently, the focus is on the use of natural gas and biomethane as means to reduce greenhouse gas emissions from transport, in particular in the case of public road transport. However, there exists some uncertainty about the expected environmental benefits of using these fuels in the urban transport sector [2-10].

Research on air pollution in Poland was conducted by the authors of article [11], in which they presented parameters for describing transport pollution, in particular in road transport modes and factors affecting their size. An analysis was performed regarding areas where concentrations of harmful substances in the air in Poland were exceeded.

In comparative studies of buses powered by $\mathrm{CNG}$ and diesel, the majority of authors (e.g. Karman in [12]) show a reduction in carbon dioxide emissions when switching from diesel to CNG. Some (Ally and Pryor [13]) have different experiences and emphasise that the specificity of bus traffic (Australia) determines that under certain conditions a CNG-powered bus can emit more pollutants than a diesel bus. Rose et al. [14] demonstrate that a $24 \%$ reduction in greenhouse gas emissions can be achieved by changing the way vehicles are powered from diesel to CNG in Canadian conditions.

The authors in the article [15] analyse the carbon footprint of buses powered by different fuels. The carbon footprint of the buses measured for the LNG bus was $63 \mathrm{~g}$ $\mathrm{CO}_{2 e} / \mathrm{pkm}$ and for a traditional diesel bus $54 \mathrm{~g} \mathrm{CO}_{2 e} / \mathrm{pkm}$. Plug-in hybrid buses had a carbon footprint of about $38 \mathrm{~g}$ $\mathrm{CO}_{2 e} / \mathrm{pkm}$ and fuel cell buses $-29 \mathrm{~g} \mathrm{CO}_{2 e} / \mathrm{pkm}$.

The analysis of exhaust emissions in real traffic conditions was also the subject of research in the article [16], in which the authors showed an underestimation of road emissions from heavy-duty vehicles. The exhaust emission indicators were higher in real driving conditions, which was due to frequent acceleration, deceleration and startstop operation. NOx emission levels were obtained in the range of $2.9-21 \mathrm{~g} / \mathrm{km}$, which were much higher than previous tests on the chassis dynamometer. Studies show that the fuel consumption rate of the vehicles tested was highly dependent on NOx emissions. The road hydrocarbon emission of LNG vehicles ranged between 2 and $10 \mathrm{~g} / \mathrm{km}$, and was significantly higher than for diesel vehicles $-0.03-0.18$ $\mathrm{g} / \mathrm{km}$.

Analyses of the use of liquefied natural gas as road fuel for heavy-duty vehicles are undertaken in the article [17]. Researchers analysed various aspects of the LNG chain in an ecological and economical way. It was concluded that higher investment in the initial phase of LNG fuel deployment could be amortised during their lifetime and that LNGfuelled trucks are cheaper and more ecological in the long term than classic diesel vehicles.

For such forecasting, the traffic model of the road network (described in the publication [18] may be used based on time series which will make it possible to link - among others - demographic and socio-economic variables. Independent factors, such as the number of passengers and the load on the lines that buses serve, also have an impact on exhaust emissions in real traffic conditions. Such forecasting of passenger flows, from the point of view of planning, designing and decision-making on urban transport, is described in the article [19]. With the use of regression methods, the daily flow of passengers in different weather conditions was estimated. It has been indicated that the daily number of passengers may depend - among others - on weather conditions: temperature and wind strength. Another factor influencing the emission of exhaust gases in real traffic conditions is the driver's behaviour. This issue is covered in Article [20], which states that the physical and mental characteristics of drivers remain unpredictable and incalculable in models for assessing their behaviour.

While type approval tests of urban buses do not fully reflect their ecological potential, the newest exhaust emissions tests from motor vehicles done in real driving conditions better reflect the correct ecological condition of such vehicles. Such tests enable, among others calibrating vehicle engines in such a way as to reduce the exhaust emissions throughout the entire range of engine operation [1].

In order to further investigate this issue, exhaust emission tests were carried out in real driving conditions of buses that met the Euro VI exhaust emission norm: one with a spark ignition engine powered by natural gas (LNG), the other with a diesel engine powered by diesel oil. 
The structure of the article is as follows: discussion of the research methodology, presentation of research objects, route, research equipment, and then presentation of research results with a discussion and summary (Figure 1).

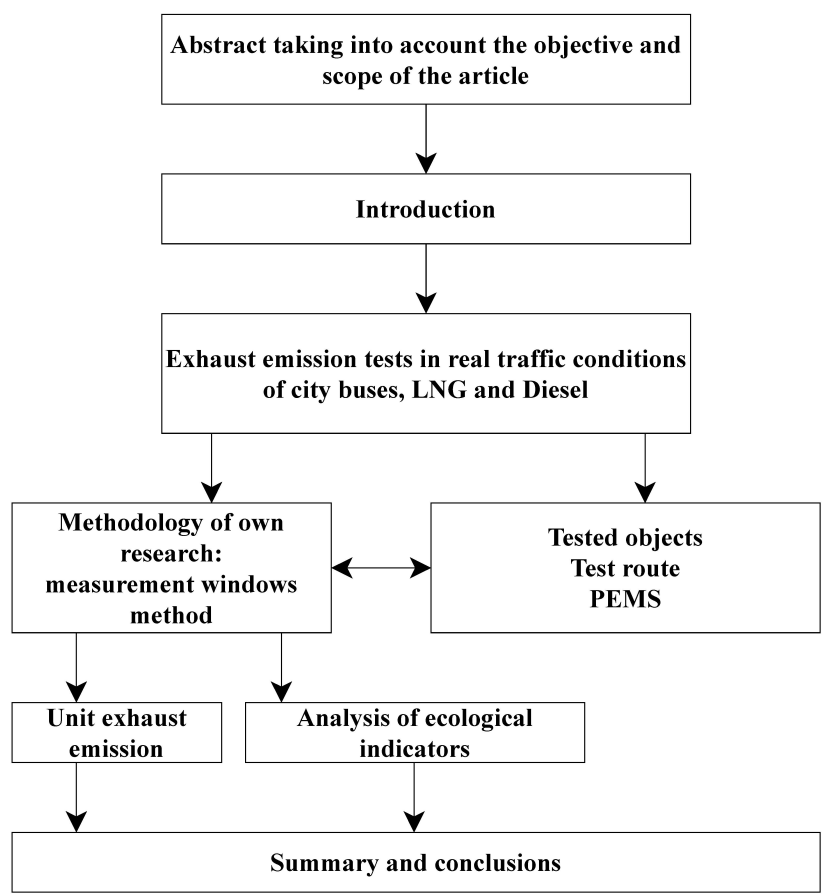

Figure 1: Structure of research.

\section{Methodology}

\subsection{Testing procedure}

In 2011, the European Union implemented the requirement to test exhaust emissions from heavy-duty vehicles in real operating conditions with the use of PEMS (Portable Emission Measurement System) devices. The methodology and research requirements in this field are described in relevant regulations [22-34], and at the same time, more work is underway to further improve these methods.

Two algorithms are used to determine the exhaust emissions of individual exhaust components in real driving conditions for heavy vehicles: one is an algorithm that uses the work performed by the drive system throughout the test and the other an algorithm that uses the carbon dioxide emissions data. Conformity factors calculated from such algorithms are typically close to each other in value, however, the decision on the ecological compatibility of the vehicle (positive/negative) is made using only the results of the algorithm based on the drive system work performed. Therefore, as part of this article, the algorithm relying on the vehicle drive operation during the emission test was used.

The European Commission Regulation 582/2011 [21] further supplemented by the Commission regulations [22-30] describes the above-mentioned exhaust emission measurement methods [31-34] while the current state and prospects for the development of liquid fuels in road transport are given in [35].

\subsubsection{Moving averaging window algorithm}

The exhaust emission of individual harmful components is determined using the moving averaging window algorithm, based on the reference mass of carbon dioxide or the reference work performed in the type approval test (for heavy vehicle engines). The principle of calculating the mass of harmful compounds is as follows: the emission of a specific compound is not calculated for the full range of data, but for its subsets where the work performed (or carbon dioxide emissions) corresponds with the work (or mass of carbon dioxide) in the type approval test. The moving averaging window algorithm uses time increments equal to the data sampling frequency (Figure 2). The results from the subsets are then used to determine the emission indicators for individual harmful exhaust components.

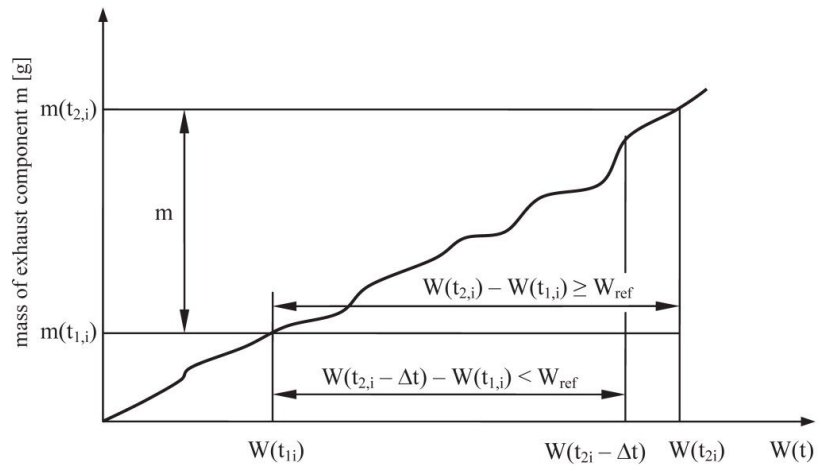

Figure 2: An algorithm for determining the emissions using the work performed in the test [21].

The duration of the $j$-th averaging window $\left(t_{2, j}-t_{1, j}\right)$ is determined according to the formula:

$$
W\left(t_{2, j}\right)-W\left(t_{1, j}\right) \geq W_{\text {ref }}
$$

where:

$W\left(t_{i, j}\right)$ - work done measured between start of the study and time $\left(t_{i, j}\right)[\mathrm{kWh}$, 
$W_{\text {ref }}$ - work done by the engine in the WHTC test [kWh], $t_{2, j}$ is then selected so that:

$$
W\left(t_{2, j}-\Delta t\right)-W\left(t_{l, j}\right)<W_{r e f} \leq W\left(t_{2, j}\right)-W\left(t_{1, j}\right)
$$

where $\Delta t$ is the data sampling rate ( $1 \mathrm{~s}$ or less).

\subsubsection{Specific emissions calculation}

The specific exhaust emissions of compounds ( $\mathrm{mg} / \mathrm{kWh}$ ) is calculated for each window as follows:

$$
e=\frac{m}{\left(W\left(t_{2, j}\right)-W\left(t_{1, j}\right)\right)}
$$

where:

$m$ - is the emitted mass of a compound [mg], $W\left(t_{2, j}\right)-W\left(t_{1, j}\right)-$ is the engine work done in the $\mathrm{j}$-th averaging window $[\mathrm{kWh}]$.

\subsubsection{Choosing the valid windows}

The algorithm uses only valid averaging windows, i.e. those in which the share of the determined engine power exceeds $20 \%$ of its maximum value. The proportion of valid windows must be greater than or equal to 0.5 for the entire test to be considered valid. If the value is less than 0.5 , the procedure is repeated with lower power thresholds. The threshold values can be decreased in $1 \%$ steps, assuming that the lowest value of the power share is $15 \%$. Any lower power threshold value invalidates the test [21-24]. The test is also void if the proportion of valid windows is less than 0.5 or if there are no valid windows for nitrogen oxides emission after using the $90^{\text {th }}$ percentile rule.

\subsubsection{Conformity factors calculation}

The conformity factor is used to determine the compliance of the vehicle in operation with the exhaust emission limits. The PEMS equipment is used to determine the emissions of individual exhaust components expressed in $\mathrm{mg}$ as a function of the engine work expressed in kWh over the entire drive test cycle. This work is broken down into sections called "windows" in the regulations. The average exhaust emissions of the individual pollutants and the work done are determined for each window. On this basis, the specific exhaust emission in $\mathrm{mg} /(\mathrm{kWh})$ is calculated and then the conformity factor $\mathrm{CF}$ according to the formula:

$$
C F=e_{i} / L_{i}
$$

where:

$e_{i}$ - specific exhaust emission of exhaust compound $i$ $[\mathrm{mg} / \mathrm{kWh}]$,

$L_{i}$ - the maximum emission limit value of exhaust component $i$ in the WHTC test $[\mathrm{mg} / \mathrm{kWh}]$.

The vehicle is deemed to meet the requirements if $90 \%$ of the CF values, determined in accordance with the measurement and calculation procedures set out in [1, 21-26], do not exceed the limit values by a factor of 1.5 , for each individual part of the test-driving cycle.

\subsection{Test vehicles}

Exhaust emission tests in real driving conditions were carried out on an articulated city bus equipped with a spark ignition engine powered by LNG fuel. Its engine displacement was $8.9 \mathrm{dm}^{3}$, and the rated power was $235 \mathrm{~kW}$. The bus was factory-equipped with an LNG-fueled engine, and the vehicle was manufactured with an installation to prepare and convert the fuel to CNG (the bus had liquefied natural gas tanks, while the power supply took place after heating and decompression - with gaseous fuel). The fuel was supplied by gas injection into the intake manifold. The bus complied with the Euro VI exhaust emission norm. Using this type of a bus for testing was dictated by the growing share of such vehicles in the urban bus fleet in many cities in Poland.

The second test vehicle was an articulated city bus equipped with a diesel engine powered by diesel fuel. The engine's displacement was $10.8 \mathrm{dm}^{3}$, with a rated power of $271 \mathrm{~kW}$. Like the previous bus (powered by LNG), the diesel fueled engine also met the Euro VI emission norm. The buses available for testing had comparable engine power per unit weight of the vehicle (Table 1).

Table 1: Tested vehicles parameters.

\begin{tabular}{lcc}
\hline & Vehicle 1 & Vehicle 2 \\
\hline Fuel type & LNG (SI) & Diesel \\
Exhaust emission norm & Euro VI & Euro VI \\
Maximum torque & $1400 \mathrm{Nm}$ & $1500 \mathrm{Nm}$ \\
Maximum engine power & $235 \mathrm{~kW}$ & $271 \mathrm{~kW}$ \\
Engine displacement & $8.9 \mathrm{dm}^{3}$ & $10.8 \mathrm{dm}^{3}$ \\
Specific engine power & $26.4 \mathrm{~kW} / \mathrm{dm}^{3}$ & $25.1 \mathrm{~kW} / \mathrm{dm}^{3}$ \\
\hline
\end{tabular}

The authors chose the city buses due to their compliance with the exhaust emission norm, but it was assumed that their mileage would not be taken into account (Table 1). This was due to the fact that the tested vehicles were man- 
Table 2: Comparison of travel parameters by an LNG-powered bus.

\begin{tabular}{lllllc}
\hline & Trip 1 & Trip 2 & Trip 3 & Trip 4 & Standard deviation \\
\hline $\mathrm{V}=0-20 \mathrm{~km} / \mathrm{h}$ & 0.499 & 0.447 & 0.496 & 0.447 & $0.26 \%$ \\
$\mathrm{~V}=20-40 \mathrm{~km} / \mathrm{h}$ & 0.339 & 0.384 & 0.327 & 0.359 & $0.19 \%$ \\
$\mathrm{~V}=40-60 \mathrm{~km} / \mathrm{h}$ & 0.162 & 0.169 & 0.177 & 0.194 & $0.06 \%$ \\
$\mathrm{a}>0$ & 0.296 & 0.319 & 0.307 & 0.301 & $0.03 \%$ \\
$\mathrm{a}<0$ & 0.334 & 0.350 & 0.341 & 0.358 & $0.03 \%$ \\
$\mathrm{~V}=0$ stop & 0.369 & 0.331 & 0.352 & 0.341 & $0.08 \%$ \\
\hline
\end{tabular}

Table 3: Comparison of travel parameters of a bus trip with a diesel engine.

\begin{tabular}{lllllc}
\hline & Trip 1 & Trip 2 & Trip 3 & Trip 4 & Standard deviation \\
\hline $\mathrm{V}=0-20 \mathrm{~km} / \mathrm{h}$ & 0.472 & 0.446 & 0.497 & 0.431 & $0.25 \%$ \\
$\mathrm{~V}=20-40 \mathrm{~km} / \mathrm{h}$ & 0.290 & 0.325 & 0.280 & 0.346 & $0.28 \%$ \\
$\mathrm{~V}=40-60 \mathrm{~km} / \mathrm{h}$ & 0.238 & 0.229 & 0.223 & 0.221 & $0.02 \%$ \\
$\mathrm{a}>0$ & 0.337 & 0.336 & 0.323 & 0.346 & $0.03 \%$ \\
$\mathrm{a}<0$ & 0.351 & 0.358 & 0.326 & 0.359 & $0.07 \%$ \\
$\mathrm{~V}=0$ stop & 0.312 & 0.306 & 0.350 & 0.294 & $0.18 \%$ \\
\hline
\end{tabular}

ufactured in 2019, and their mileage was approximately $150,000 \mathrm{~km}$.

Table 2 and 3 show the comparative parameters of travel for both buses. They are in good compatibility.

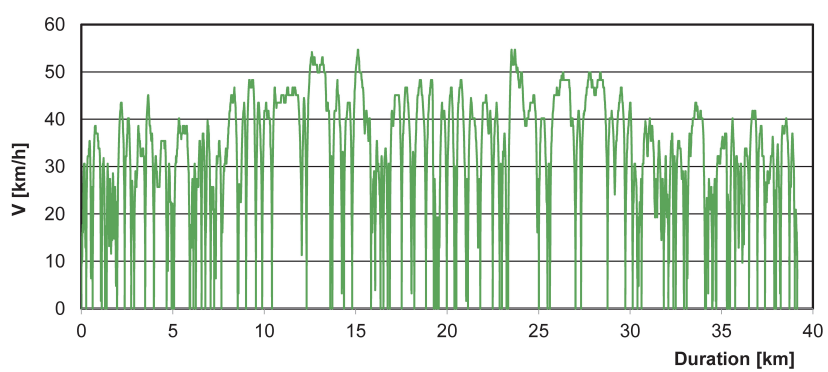

(a)

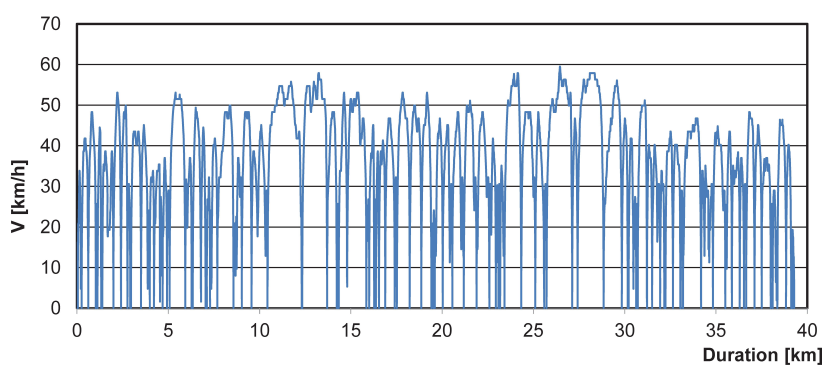

(b)

Figure 3: Speed profile and route diagram for road emission testing: a) LNG, b) Diesel.

\subsection{Test route}

Emission tests of the urban buses were carried out in real driving conditions on an urban route with a length of about $40 \mathrm{~km}$, during regular use of these vehicles in normal traffic (Figure 3). Road tests were carried out in one of the major Polish cities (Warsaw). The selected test route was the route on which the buses typically traveled in their daily transport routine. The buses were tested with normal driving patterns (stops) under normal road traffic conditions without passenger load.

\subsection{Measuring apparatus}

Road emission tests were performed, and data recorded using PEMS devices. The mobile systems for measuring exhaust emissions of harmful gas compounds (Figure 4) record the concentration of exhaust gas components such as: carbon monoxide, carbon dioxide, nitrogen oxides and hydrocarbons. The exhaust gas sample is taken using a heated line at $191^{\circ} \mathrm{C}$ and delivered to the measurement system. The exhaust gas is filtered to remove particulate matter and in the next step the hydrocarbon concentration is measured using a flame ionization detector (FID). Then, the sample is cooled down to $4^{\circ} \mathrm{C}$, and the concentration of nitrogen oxide and nitrogen dioxide is measured in a nondispersive (ultraviolet) analyzer (NDUV). Next, the exhaust gas sample is sent to a non-dispersive (infrared) analyzer (NDIR) where the concentration of carbon monoxide and 
Table 4: Measurement parameters of the mobile exhaust measuring system [21].

\begin{tabular}{ccc}
\hline Parameter & Measurement method & Accuracy \\
\hline $\mathrm{NOx}$ & $\mathrm{NDUV}-$ non-dispersive, & $\pm 3.0 \%$ \\
$\mathrm{THC}$ & range NO: $0-2500 \mathrm{ppm}, \mathrm{NO}_{2}: 0-500 \mathrm{ppm}$ & \\
& $\mathrm{FID}-$ flame-ionization, & $\pm 2.5 \%$ \\
$\mathrm{CO}, \mathrm{CO}_{2}$ & range $0-10,000 \mathrm{ppm}$ & \\
$\mathrm{O}_{2}$ & $\mathrm{NDIR}-$ non-dispersive (infrared), range $0-20 \%$ & $\pm 3.0 \%$ \\
Sampling & electrochemical, range $0-22 \%$ & $\pm 1.0 \%$ \\
Exhaust flow & $1-4 \mathrm{~Hz}$ & - \\
& mass flow meter & $\pm 2.5 \%$ \\
Diagnostic system & $\mathrm{T}_{\max }=700^{\circ} \mathrm{C}$ & $\pm 1.0 \%$ \\
\hline
\end{tabular}

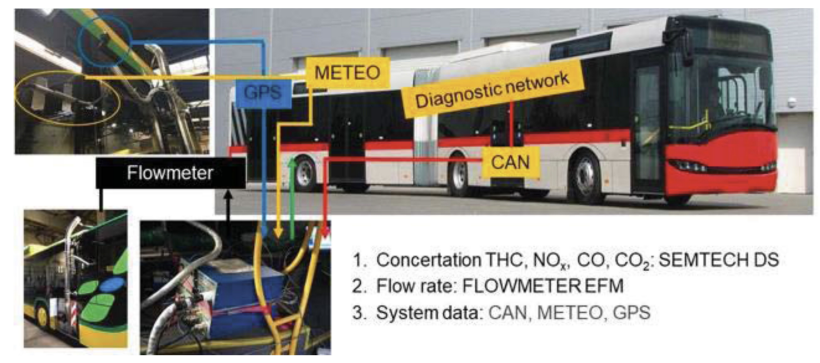

Figure 4: Technical parameters of the PEMS measuring device.

carbon dioxide is measured. The device also allows recording the parameters taken from the vehicle's diagnostic system as well as its geographic location using the GPS module (Table 4).

The measurement system used for testing also allows the registration of the exhaust gas flow (the flow meter was selected on the basis of the engine displacement for the tested buses). For the proper operation of the system, it is necessary to connect a GPS receiver and a portable weather station.

\section{Results and discussion}

The exhaust emission tests of city buses equipped with engines fueled with either natural gas or diesel fuel, carried out in real driving conditions, allowed to determine the average exhaust emission and average fuel consumption values (among other things, with four trips completed for each bus). The obtained results made it possible to conclude that in terms of the specific emission of nitrogen oxides, this emission was comparable for a bus with an engine fueled with natural gas through an LNG system and a bus with a diesel engine (Figure 5).

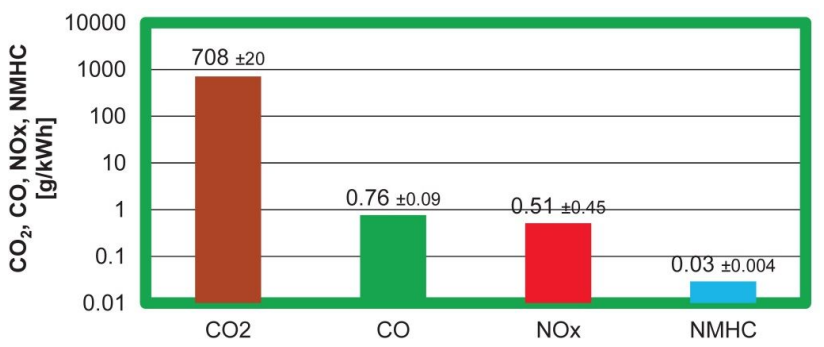

Figure 5: Average road exhaust emissions and average fuel consumption of a bus equipped with a spark ignition engine fueled with natural gas (LNG).

This would indicate that the exhaust aftertreatment systems used in these vehicles (for LNG vehicle - a threeway catalyst and for diesel engine - an SCR system) were highly efficient. At the same time, this indicates the relative advantage of the tested LNG bus for the reduction of specific NOx emissions (this reduction is approx. 3.8\%), which is emphasized in relation to CNG buses in the study [10]. The bus with a natural gas engine emitted almost as much carbon dioxide (by approx. 1.7\%) as the bus with a diesel engine - which also indicates similar fuel consumption values, as these values are correlated. Hence the legitimacy of using biomethane to reduce these emissions over the life cycle of an LNG bus. At the same time, this indicates the relative advantage of the tested LNG bus for the reduction of specific $\mathrm{CO}_{2}$ emissions, which is emphasized in relation to CNG buses in the study [10]. In the case of the specific carbon monoxide emission, the bus with a natural gas engine (LNG) emitted about 20\% more than the bus with a diesel engine, while the specific emission of non-methane hydrocarbons value was about $90 \%$ lower for the bus powered with LNG compared to the diesel vehicle (Figure 6).

The buses exhaust emission tests in real driving conditions also allowed to determine the vehicle fuel consump- 


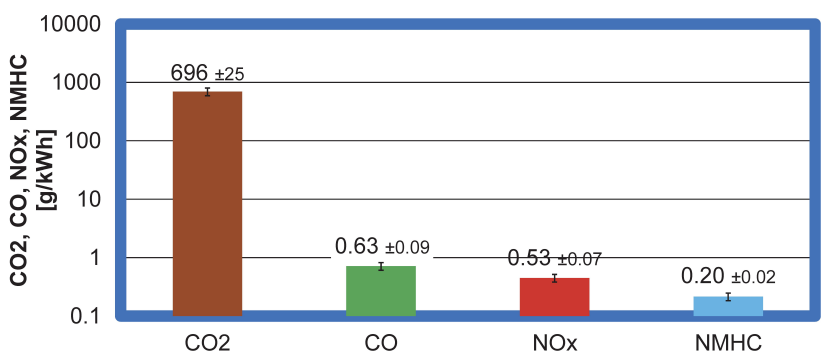

Figure 6: Average road exhaust emissions and average fuel consumption of a bus equipped with a diesel engine.

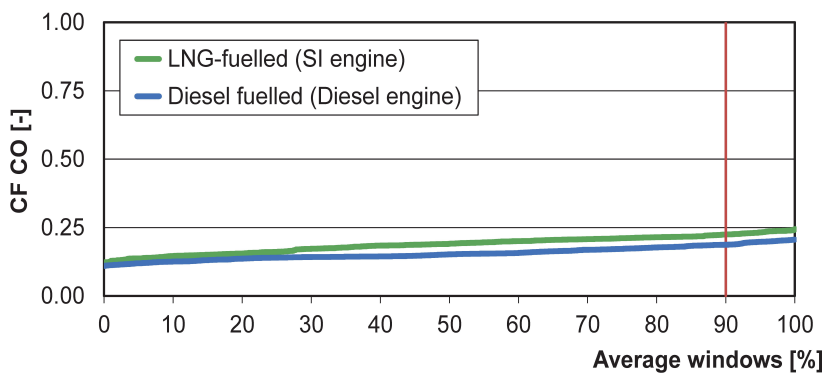

Figure 7: Measured conformity factor values for the specific emission of carbon monoxide for the two tested buses.

tion. In order to compare the values, the fuel consumption was converted from $\mathrm{m}^{3} / 100 \mathrm{~km}(\mathrm{LNG})$ and $\mathrm{dm}^{3} / 100 \mathrm{~km}$ (Diesel) to $\mathrm{MJ} / 100 \mathrm{~km}$. Thanks to this conversion it became possible to directly compare the results:

- for an LNG-powered bus the fuel consumption was $2182 \mathrm{MJ} / 100 \mathrm{~km}$;

- for a diesel-fueled bus the fuel consumption was 1523 $\mathrm{MJ} / 100 \mathrm{~km}$.

The analysis of the specific exhaust emission values determined in the measurement windows leads to the conclusion that for the tested buses, the value of the $90^{\text {th }}$. percentile of the conformity factor for the specific emission of carbon monoxide does not exceed the maximum allowable conformity factor for this compound (Figure 7). The tested buses did not exceed this limit- the permissible exhaust emission value of 1.5 of the limit values was not reached, it reached only about $20 \%$ (the CF value did not exceed 0.25).

The comparison of the specific emission of nitrogen oxides was shown in Figure 8. The obtained slight exceedances of the 1.5 limit for the $\mathrm{CF}$ value indicate the correct operation of the exhaust aftertreatment systems. At the same time, it should be noted that the test procedure was not fully consistent with the type approval procedure, as the tests presented in this article concerned only urban driving, which was required by the specificity of the tested vehicles operation. An issue that remains unresolved in the

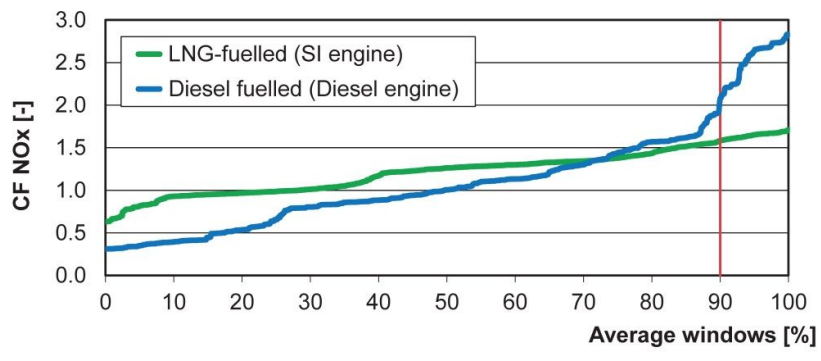

Figure 8: Conformity factor for specific nitrogen oxides emissions for the two tested buses.

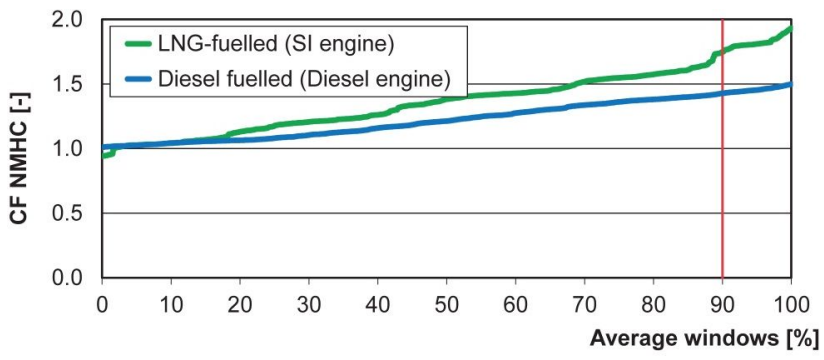

Figure 9: Conformity factor for specific non-methane hydrocarbons emissions for the two tested buses.

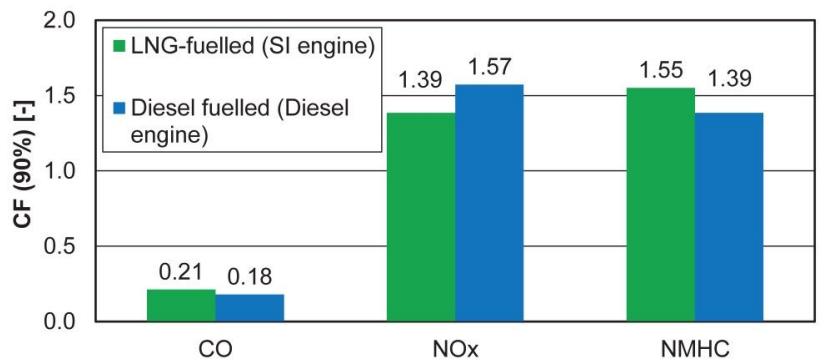

Figure 10: The conformity factors value corresponding to the $90^{\text {th }}$ percentile for the measured exhaust components (permitted limit value of $C F=1.5$ ).

context of further studies of buses is the repeated measurement of the specific emission of non-methane hydrocarbons (Figure 9). A relatively small exceedance of the permissible conformity factor value in the final measurement windows for this exhaust component was recorded.

The presented graphs of cumulative conformity factors values did not reflect their exact values corresponding to $90 \%$ of measurement windows. The exact values - determined in accordance with the test procedure presented in the European Union Regulation were shown in Figure 10. The analysis of the figure showed that the emission indicators are similar for the tested buses, and the differences do not exceed $20 \%$ of the values.

Based on the significant similarity of the conformity factor curves, it was possible to state that a significant exhaust emissions measurement repeatability and, at the 
same time, the reliability of road tests performed with the use of city buses, was achieved. The routes were characterized by high repeatability of road traffic conditions during the tests, thanks to which the number of factors affecting the repeatability of measurements was minimized.

\section{Conclusions}

The conducted exhaust emission tests of buses powered by different fuels did not fully reflect the type approval tests. The adopted research methodology was largely based on the assumptions of such tests, but due to the nature of city buses operation - only their expected real operating conditions were used for the research. The considered issues were aimed at obtaining information on the preliminary analysis of exhaust emissions and fuel consumption in urban transport for buses with various types of combustion engines in real driving conditions.

The analysis of the obtained results showed that the exhaust emission of carbon dioxide in real driving conditions was higher for a bus with an LNG engine than for a bus equipped with a diesel engine. The use of biomethane instead of $L N G$ as fuel could reduce these emissions to close to zero when the entire life cycle of the vehicle is considered. When comparing buses in terms of specific emissions of carbon monoxide, higher values for the LNG bus than for the vehicle equipped with a diesel engine were found. The specific emissions of nitrogen oxides were very close in value, and further tests should be performed to unambiguously state the general relationship between them. The specific emission of non-methane hydrocarbons in the LNGpowered bus was several dozen times lower than in the bus powered by diesel fuel.

The analysis showed that the emission indicators (conformity factors) are similar for the tested buses, and the differences do not exceed $20 \%$ of the values. For a detailed analysis of the issues under consideration, a much larger program of tests should be carried out with the use of various buses with tested drives and fuel types to confirm the obtained relationships through statistical analysis.

\section{References}

[1] Johnson T, Joshi A. Review of vehicle engine efficiency and emis sions. SAE International Journal of Engines. 2018;11(6):1307-30

[2] Gis M. Comparative studies exhaust emissions of the Euro VI buses with diesel engine and spark-ignition engine CNG fuelled in real traffic conditions. MATEC Web of Conference. 2017;18
[3] Gis M. Assessment of exhaust emissions from vehicles in real traffic conditions. IOP Conference Series: Earth and Environmental Science. 2019:214

[4] Merkisz J, Pielecha J, Gis W. Comparison of vehicle emission factors in NEDC cycle and road test. Proceedings of the Ninth Asia-Pacific International Symposium on Combustion and Energy Utilization. 2008:477-482

[5] Merkisz J, Pielecha J, Radzimirski S. New Trends in Emission Control in the European Union. Springer Tracts on Transportation and Traffic. 2014;4:67-90

[6] Merkisz J, Fuc P, Lijewski P, Pielecha J. Actual emissions from urban buses powered with diesel and gas engines. Transportation Research Procedia. 2016;14:3070-8

[7] Merkisz J, Pielecha J, Gis W. On-road testing and characterization of the exhaust emissions of light-duty vehicles. Sustainable Development and Planning. 2009:1-2(120):439-49

[8] Nowak M, Pielecha J. Comparison of exhaust emission on the basis of Real Driving Emissions measurements and simulation. MATEC Web of Conference. 2017;118

[9] Merkisz J, Pielecha J. Conversion of the exhaust emission results obtained from combustion engines of heavy-duty vehicles. IOP Conference Series: Materials Science and Engineering. 2016;148

[10] Kollamthodi S, Norris J, Dun C, Brannigan C, Twisse F, Biedka M, et al. The role of natural gas and biomethane in transport sector. Report ED 61479 Ricardo. 2016

[11] Ambroziak T, Jachimowski R, Pyza D, Szczepański E. Analysis of the traffic stream distribution in terms of identification of areas with the highest exhaust pollution. The Archives of Transport. 2014;32(4)

[12] Karman D. Life-cycle analysis of GHG emissions for CNG and diesel buses in Beijing. EIC Clim. Chang. Technol. 2006;6:1-6

[13] Ally J, Pryor J. Life-cycle assessment of diesel, natural gas and hydrogen fuel cell bus transportation systems. J. Power Sources. 2007;170:401-11

[14] Rose L, Hussain M, Ahmed S, Malek K, Costanza R, Kjeang E. A comparative life cycle assessment of diesel and compressed natural gas, powered refuse collection vehicles in a Canadian city. Energy Policy. 2013;52:453-61

[15] Chang CC, Liao YT, Chang YW. Life cycle assessment of alternative energy types - including hydrogen - for public city buses in Taiwan. International Journal of Hydrogen Energy. 2019;44(33):18472-82

[16] Lv L, Ge Y, Ji Z, Tan J, Wang X, Hao L, et al. Regulated emission characteristics of in-use LNG and diesel semi-trailer towing vehicles under real driving conditions using PEMS. Journal of Environmental Sciences. 2020;88:155-64

[17] Smajla I, Karasalihović Sedlar D, Drljača B, Jukić L. Fuel switch to LNG in heavy truck traffic. Energies. 2019;12(515)

[18] Duraku R, Ramadani R. Development of traffic volume forecasting using multiple regression analysis and artificial neural network. Civil Engineering Journal. 2019:5(8)

[19] Guo Y, Wang X, Xu Q, Liu S, Liu S, Han J. Weather impact on passenger flow of rail transit lines. Civil Engineering Journal. 2020;6(2)

[20] Muslim NHB, Shafaghat A, Keyvanfar A, Ismail M. Green driver: driving behaviors revisited on safety. Archives of Transport. 2018;47(3):49-78

[21] Commission Regulation (EU) 2011 No 582/2011 of 25 May 2011implementing and amending Regulation (EC) No 595/2009 of the European Parliament and of the Council with respect to emis- 
sions from heavy duty vehicles (Euro $\mathrm{VI}$ ) and amending Annexes I and III to Directive 2007/46/EC of the European Parliament and of the Council

[22] Commission Regulation (EU) 2012 No 64/2012 of 23 January 2012 amending Regulation (EU) No 582/2011 implementing and amending Regulation (EC) No 595/2009 of the European Parliament and of the Council with respect to emissions from heavy duty vehicles (Euro VI)

[23] Commission Regulation (EU) 2013 No 519/2013 of 21 February 2013 adapting certain regulations and decisions in the fields of free movement of goods, freedom of movement for persons, right of establishment and freedom to provide services, company law, competition policy, agriculture, food safety, veterinary and phytosanitary policy, fisheries, transport policy, energy, taxation, statistics, social policy and employment, environment, customs union, external relations, and foreign, security and defence policy, by reason of the accession of Croatia

[24] Commission Regulation (EU) 2014 No 136/2014 of 11 February 2014 amending Directive 2007/46/EC of the European Parliament and of the Council, Commission Regulation (EC) No $692 / 2008$ as regards emissions from light passenger and commercial vehicles (Euro 5 and Euro 6) and Commission Regulation (EU) No 582/2011 as regards emissions from heavy duty vehicles (Euro VI)

[25] Commission Regulation (EU) 2014 No 133/2014 of 31 January 2014 amending, for the purposes of adapting to technical progress as regards emission limits, Directive 2007/46/EC of the European Parliament and of the Council, Regulation (EC) No 595/2009 of the European Parliament and of the Council and Commission Regulation (EU) No 582/2011

[26] Commission Regulation (EU) 2014 No 627/2014 of 12 June 2014 amending Regulation (EU) No582/2011 for the purposes of adapting it to technical progress as regards particulate matter monitoring by the on-board diagnostic system

[27] Commission Regulation (EU) 2016 No 2016/1718 of 20 September 2016 amending Regulation (EU) No 582/2011 with respect to emissions from heavy-duty vehicles as regards the provisions on testing by means of portable emission measurement systems (PEMS) and the procedure for the testing of the durability of replacement pollution control devices

[28] Commission Regulation (EU) 2017 No 2017/1347 of 13 July 2017 correcting Directive 2007/46/EC of the European Parliament and of the Council, Commission Regulation (EU) No 582/2011 and Commission Regulation (EU) 2017/1151 supplementing Regulation (EC) No 715/2007 of the European Parliament and of the Council on type-approval of motor vehicles with respect to emissions from light passenger and commercial vehicles (Euro 5 and Euro 6) and on access to vehicle repair and maintenance information, amending Directive 2007/46/EC of the European Parliament and of the Council, Commission Regulation (EC) No 692/2008 and Commission Regulation (EU) No 1230/2012 and repealing Regulation (EC) No 692/2008
[29] Commission Regulation (EU) 2017 No 2017/2400 of 12 December 2017 implementing Regulation (EC) No 595/2009 of the European Parliament and of the Council as regards the determination of the $\mathrm{CO} 2$ emissions and fuel consumption of heavy-duty vehicles and amending Directive 2007/46/EC of the European Parliament and of the Council and Commission Regulation (EU) No 582/2011

[30] Commission Regulation (EU) 2018 No 2018/932 of 29 June 2018 amending Regulation (EU) No 582/2011as regards the provisions on testing by means of portable emission measurement systems (PEMS) and the requirements for universal fuel range typeapproval

[31] RDE Act 12016 Commission Regulation (EU) 2016/427 of 10 March 2016 amending Regulation (EC) No 692/2008 as regards emissions from light passenger and commercial vehicles (Euro 6)

[32] RDE Act 22016 Commission Regulation (EU) 2016/646 of 20 April 2016 amending Regulation (EC) No 692/2008 as regards emissions from light passenger and commercial vehicles (Euro 6)

[33] RDE Act 32017 Commission Regulation (EU) 2017/1154 of 7 June 2017 amending Regulation (EU) 2017/1151 supplementing Regulation (EC) No 715/2007 of the European Parliament and of the Council on type-approval of motor vehicles with respect to emissions from light passenger and commercial vehicles (Euro 5 and Euro 6) and on access to vehicle repair and maintenance information, amending Directive 2007/46/EC of the European Parliament and of the Council, Commission Regulation (EC) No 692/2008 and Commission Regulation (EU) No 1230/2012 and repealing Regulation (EC) No 692/2008 and Directive 2007/46/EC of the European Parliament and of the Council as regards real-driving emissions from light passenger and commercial vehicles (Euro 6)

[34] RDE Act 42018 Commission Regulation (EU) 2018/1832 of 5 November 2018 amending Directive 2007/46/EC of the European Parliament and of the Council, Commission Regulation (EC) No 692/2008 and Commission Regulation (EU) 2017/1151 for the purpose of improving the emission type approval tests and procedures for light passenger and commercial vehicles, including those for in-service conformity and real-driving emissions and introducing devices for monitoring the consumption of fuel and electric energy

[35] Zöldy M, Török Á. Road transport liquid fuel today and tomorrow: Literature overview. Periodica Polytechnica Transportation Engineering.2015;43(4) 